\title{
Ecdeiocoleaceae and Joinvilleaceae, sisters of Poaceae (Poales): evidence from rbcL and matK data
}

\author{
Adam D. Marchant and Barbara G. Briggs ${ }^{1}$ \\ Botanic Gardens Trust, Mrs Macquaries Rd, Sydney, NSW 2000, Australia \\ ${ }^{1}$ Author for correspondence: barbara.briggs@rbgsyd.nsw.gov.au
}

\begin{abstract}
Within Poales, the clade (Poaceae, Ecdeiocoleaceae, Joinvilleaceae) has previously received robust support from DNA sequence data from a range of genes. However, the question of which family (or set of families) is the sister group of Poaceae has not been answered with any degree of confidence, to date. Using Ecdeiocolea monostachya as the only representative of its family, other researchers have found the clade to resolve (although mostly with low levels of support) as (Joinvillea (Ecdeiocolea, Poaceae)). We now provide mat $\mathrm{K}$ and $r b c \mathrm{~L}$ data for Georgeantha hexandra, the sole species in the other genus of Ecdeiocoleaceae, in addition to further sampling of other closely related Poales families. Analyses of our data support the alternative topology of (Ecdeiocoleaceae, Joinvilleaceae) as sister to Poaceae and also help to resolve the position of Flagellariaceae. Flagellaria groups with (Poaceae, Ecdeiocoleaceae, Joinvilleaceae) in a graminid clade that is sister to the restiid clade (Anarthriaceae, Restionaceae, Centrolepidaceae) in analyses of mat $\mathrm{K}$ or $m a t \mathrm{~K}+r b c \mathrm{~L}$ data. A high rate of base substitution has previously been noted in Poales; branch lengths in Ecdeiocoleaceae are comparable with those in Poaceae.
\end{abstract}

\section{Introduction}

The molecular phylogeny of Poales (APG 2003) has been the subject of much recent interest. Attention has particularly focussed on six plant families (Ecdeiocoleaceae, Joinvilleaceae, Flagellariaceae, Restionaceae, Centrolepidaceae and Anarthriaceae) that, with Poaceae, form the graminoid clade (Kellogg 2000, Bremer 2002) or 'core Poales' clade (Poales sensu stricto) of Barker et al. (2000) and Michelangeli et al. (2003). Of these, Ecdeiocoleaceae is endemic to southwestern Australia and was distinguished from Restionaceae by Cutler and Shaw (1965), largely on the basis of differences in culm anatomy (Cutler 1969). The species of Ecdeiocoleaceae, Ecdeiocolea monostachya F. Muell. ${ }^{1}$ and Georgeantha hexandra B.G. Briggs \& L.A.S. Johnson, both occur in semiarid regions, whereas Joinvilleaceae and Flagellariaceae occur widely in the Old World tropics and Pacific.

${ }^{1}$ Since this paper was submitted, a second species of Ecdeiocolea (still unnamed) has been distinguished (Briggs, unpublished). All data reported here for Ecdeiocolea refer to E. monostachya. 
Various studies have identified Joinvilleaceae as a possible sister group of Poaceae (e.g. Campbell \& Kellogg 1987, Chase et al. 1995, Stevenson \& Loconte 1995, Kellogg 2000, GPWG 2001) while, until molecular data became available, Ecdeiocoleaceae were mostly regarded as more closely allied to Restionaceae than to Poaceae. Previously Briggs et al. (2000), on the basis of chloroplast DNA data, drew attention to Ecdeiocoleaceae as part of a small clade centred on Poaceae within the graminoid Poales. Subsequently Bremer (2002), using $r b c \mathrm{~L}$ and atpB DNA sequence data, identified (Joinvilleaceae, Ecdeiocoleaceae, Poaceae) as a clade (here referred to as the JEP clade, following Hilu 2004). Bremer also concluded that Ecdeiocoleaceae is sister to Poaceae, a position which was also supported by Duvall (2003). Michaelangeli et al. (2003), using morphology with atpA and rbcL DNA sequence data, similarly placed Ecdeiocoleaceae as sister to Poaceae, noting that this grouping had low jackknife support but that alternative arrangements among the JEP families had even lower values. Hilu (2004) presented a hypothesis of chromosomal evolution in Poaceae, similarly placing Joinvilleaceae as sister to (Ecdeiocoleaceae, Poaceae). In Linder and Rudall's (2005) phylogenetic hypothesis of 'core Poales' the JEP clade (their graminid clade) is sister to a restiid clade. Thus the graminoid Poales (= 'core Poales') consist of the graminid (or JEP) clade and the restiid clade (Anarthriaceae sens. lat., Restionaceae, Centrolepidaceae), together with Flagellariaceae.

That Ecdeiocoleaceae is the single sister of Poaceae was further supported by results from a large $r b c L$ data set for monocot taxa (Janssen \& Bremer 2004) and a sevengene data set including nuclear, plastid and mitochondrial sequences (Chase et al. 2006). Givnish et al. (2006), using $n d h \mathrm{~F}$ data, however, placed Ecdeiocolea as sister to (Joinvillea, Poaceae) but noted that this topology collapsed to a trichotomy in the strict consensus tree. Preliminary maximum parsimony analysis of 17-gene plastid data provides unstable results concerning the sister group of the grasses, for different taxon samplings (JM Saarela \& SW Graham, unpubl. data, pers. com.). In most of the studies mentioned, Ecdeiocoleaceae was represented only by Ecdeiocolea.

Flagellaria, the sole genus of its family, has been placed either as sister to the rest of the graminid clade (Bremer 2002, Chase 2004, Chase et al. 2006) or as sister to graminids plus restiids (Graham et al. 2006). The placement of Flagellaria within Poales has remained somewhat uncertain (Linder \& Rudall 2005, Givnish et al. 2006).

Doyle et al. (1992) and Michelangeli et al. (2003) investigated three large inversions in the chloroplast DNA of Poales, and found that the 28 kilobase and $6 \mathrm{~kb}$ inversions are synapomorphies of Joinvilleaceae, Ecdeiocoleaceae and Poaceae, while the trnT inversion is apparently autapomorphic in Poaceae. These inversions therefore do not help to resolve the trichotomy of the JEP families, but for the record we report additional results from some other Poales taxa.

This study adds to the relevant DNA sequence data, especially by including the matK sequence for Georgeantha. To investigate the difference between our conclusions and those of others who used different taxonomic sampling, we also present results from analyses that vary the taxonomic sampling and method of analysis of our data. 


\section{Materials and methods}

Taxonomic and genomic sampling: this study analysed chloroplast DNA sequence data from $r b c \mathrm{~L}$ and $m a t \mathrm{~K}$ of two species in Ecdeiocoleaceae, two in Joinvilleaceae and one of Flagellariaceae. Three samples of Ecdeiocolea and three of Georgeantha were sequenced, to check that the sequences used in the analysis were representative of each taxon; all have been submitted to GenBank but only one example from each taxon is included in the analyses ${ }^{2}$. Poaceae sampling reflected the clades indicated by the Grass Phylogeny Working Group (GPWG 2001) with Anomochloa, Streptochaeta, and Pharus representing basal clades, Oryza, Melica and Triticum the BEP clade (Bambusoideae, Ehrhartoideae, Pooideae), and Aristida, Arundo, Danthonia, Zeugites, Zea and Eragrostis from the PACCAD clade (Panicoideae, Arundinoideae, Centothecoideae, Chloridoideae, Aristoideae, Danthonioideae). Where sequences were available in GenBank, a representative was chosen from each subfamily recognised in the GPWG classification.

We have incorporated sequences from GenBank, as well as sequence data on $r b c \mathrm{~L}$ that we (Briggs et al. 2000) and others have published previously, and we provide new sequence data for $r b c \mathrm{~L}$ from a further nine taxa, and matK from 15 taxa. Vouchers have been placed in the National Herbarium of New South Wales; particulars of the taxa (including authorities for names), vouchers and GenBank accession numbers are given in Table 1. For three genera of Poaceae (Eragrostis, Melica and Aristida) rbcL and matK data were available in GenBank only from different species of the genus; the relevant species for each gene are listed in Table 1. We also experimented with the use of different sets of outgroup taxa.

DNA extraction and sequencing: DNA extraction, PCR conditions and primers used for $r b c \mathrm{~L}$ have been described previously (Briggs et al. 2000). Amplification of trnK used two primers described by Johnson and Soltis (1995); the sequences of these are listed in Table 2, along with the internal sequencing primers used. The PCR program used was $95^{\circ} \mathrm{C}$ for $5 \mathrm{~min}$, then 35 repetitions of $\left(95^{\circ} \mathrm{C}\right.$ for 30 s, $55^{\circ} \mathrm{C}$ for 30 s and $72^{\circ} \mathrm{C}$ for 2 min) with a final $10 \mathrm{~min}$ at $72^{\circ} \mathrm{C}$, in a Corbett Research Palm Cycler. The polymerase enzyme used was 'BioTaq' (Bioline, Lukenwalde, Germany). Other details of PCR and subsequent sequencing are as given previously (Briggs et al. 2000). The portion of $r b c \mathrm{~L}$ included consists of 1210 aligned bases, corresponding to positions 83 through 1292 of the gene in the Oryza sativa complete chloroplast DNA reference sequence (GenBank accession X15901).

Sequence alignment and analysis: sequences were aligned by CLUSTAL W, with modification by eye, using the program BioEdit (Hall 1999) version 5.0.6. Parsimony analyses used version $4.0 \mathrm{~b} 10$ of PAUP* (Swofford 2001) for Power PC. The majority rule consensus trees represent the result of 1000 bootstrap replicates, from full heuristic searches with random taxon addition. The sets of sequence data for the regions of chloroplast DNA were analysed separately and in combination, using parsimony and

${ }^{2}$ In Ecdeiocolea monostachya the three $r b c \mathrm{~L}$ sequences were identical; for mat $\mathrm{K}$ two of the sequences were identical but differed from the third in having two separate single-codon insertions. In Georgeantha hexandra the $r b c \mathrm{~L}$ and matK sequences each showed a singlenucleotide substitution in one of the samples. 
maximum likelihood (ML) criteria. ML analyses (with ML parameters estimated as part of the ML analysis) used either the default options or the TVM+I+G model selected by the Akaike information criterion (AIC) in Modeltest 3.7 (Posada \& Crandall 1998). Since our findings for the sister group of Poaceae differ from those found in a number of other studies, and since Ecdeiocoleaceae was represented in those other studies by Ecdeiocolea alone, rather than by both genera of the family, we repeated some of the analyses omitting data either from Ecdeiocolea or from Georgeantha. In Fig. 1 the topology resulting from PAUP ${ }^{\star}$ analysis, from the consensus of 1000 bootstrap replicates, analysed using the criterion of maximum parsimony, is combined with relative branch lengths calculated using the DNAPARS program (in PHYLIP version 3.6) for mapping characters onto the topology, a procedure suggested by Felsenstein (2004). The representatives of Restionaceae, Anarthriaceae and Centrolepidaceae were used to root the tree. Percentage bootstrap support values for nodes are shown.

Inversions in the chloroplast genome: the approach of Doyle et al. (1992) and Michelangeli et al. (2003) was followed to determine the presence or absence of the $28 \mathrm{~kb}$ inversion previously reported in some Poales. This used primer pairs that span the ends of the inverted region and that are diagnostic for either the inverted or the uninverted sequence. The presence of the inversion was indicated by amplification with primer combinations $r p s 14+\operatorname{trn} \mathrm{R}$ at the rps 14 end of the inversion or by G-UCC3' + G-GCC at the trnG-UCC end. Absence of the inversion was indicated by amplification with primers $r p s 14+$ G-GCC and G-UCC3' + trnR at the respective positions. Vouchers for the taxa studied are indicated in Table 1.

\section{Results}

Figure 1 illustrates our best inference of relationships of the taxa, based on the combined $r b c \mathrm{~L}$ and $m a t \mathrm{~K}$ sequence data summarised in Table 3 . Since matK provided more parsimony informative characters than $r b c \mathrm{~L}$, the combined-data tree largely reflects the findings from mat $\mathrm{K}$ alone. The analyses gave the following results:

(1) The JEP clade is robustly supported with $100 \%$ bootstrap support in all parsimony analyses.

(2) All parsimony analyses that included both genera of Ecdeiocoleaceae gave bootstrap values of $95 \%$ or higher to the clade (Ecdeiocolea, Georgeantha).

(3) The topology ((Joinvilleaceae, Ecdeiocoleaceae) Poaceae) is supported when all relevant data from this study are included. When both Ecdeiocolea $(\mathrm{Ec})$ and Georgeantha $(\mathrm{Ge})$ are included in the analysis, the $(\mathrm{J},(\mathrm{Ec}, \mathrm{Ge}))$ clade receives $97 \%$ or $98 \%$ support (depending on the outgroups used) from $r b c \mathrm{~L}+$ matK data, or $93 \%$ support from matK alone. When Ecdeiocoleaceae is represented by Ecdeiocolea alone, the (J,Ec) clade receives low or very low support: $70 \%$ from $r b c \mathrm{~L}+m a t \mathrm{~K}$ data, or $51 \%$ or $55 \%$ from matK alone. 


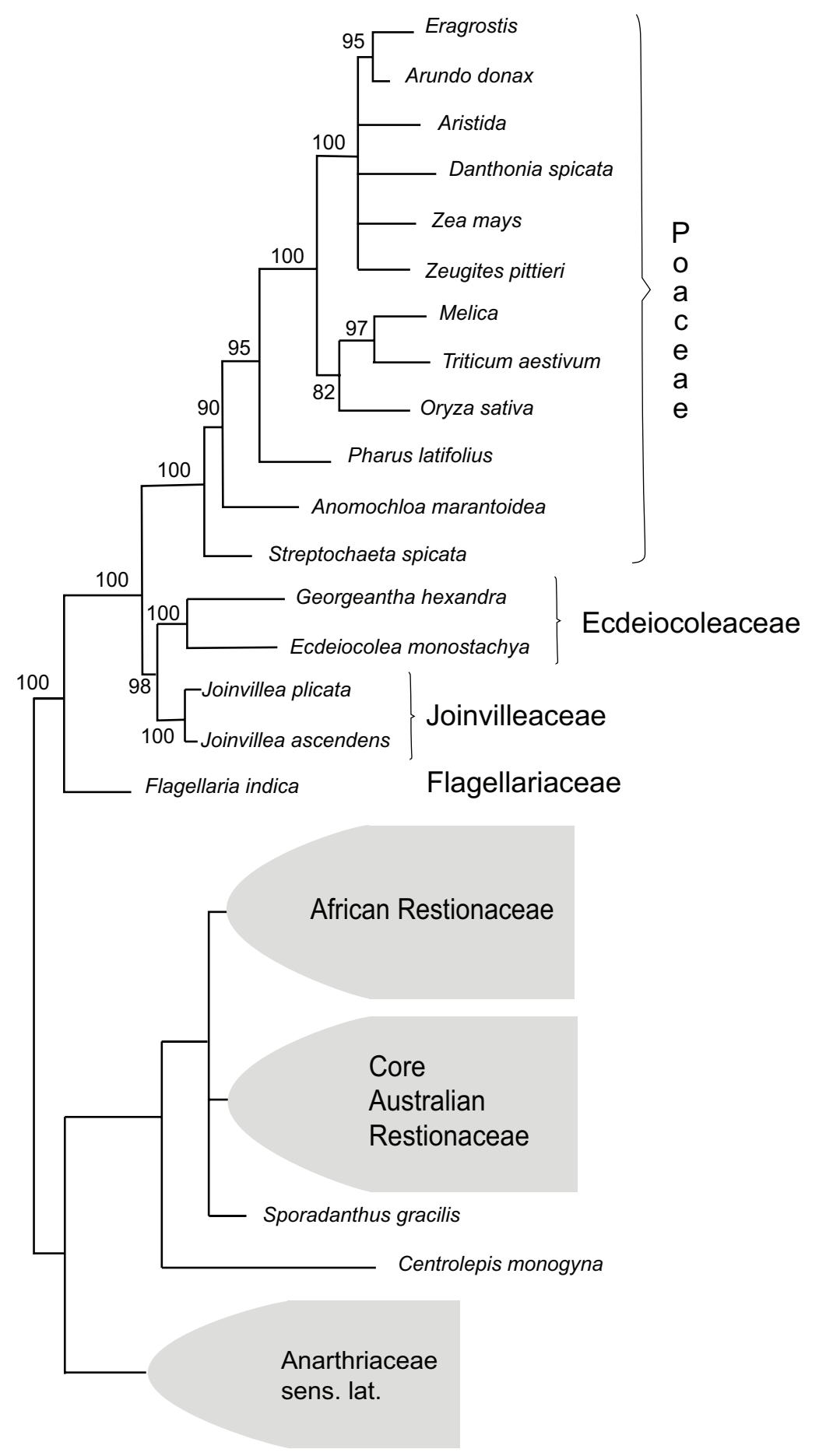

Fig. 1. Consensus tree from analysis of combined $r b c \mathrm{~L}$ and mat $\mathrm{K}$ sequence data (see text). Percentage bootstrap support values for nodes are shown. 
Table 1. Voucher information and GenBank accession numbers for taxa used in this study.

Source and voucher details are given for new sequences; vouchers are placed in the NSW herbarium, except for two collections by Linder et al. deposited at the Institute of Systematic Botany, University of Zurich (Z). Vouchers for study of the 28-kb chloroplast DNA inversion are marked*.

Taxon

\section{Anarthriaceae}

Anarthria prolifera R.Br.

DQ307438

DQ257499

Meney s.n. Jarrahdale, W.A.

Hopkinsia adscendens

AF148777

B.G.Briggs \&

L.A.S.Johnson

H. anoectocolea

(F.Muell.)

D.F.Cutler

Lyginia barbata R.Br.

AF148787

\section{Centrolepidaceae}

Centrolepis monogyna (Hook.f.) Benth.

\section{Cyperaceae}

Scirpodendron ghaeri Merrill

AB0888323

AB088804

\section{Ecdeiocoleaceae}

Ecdeiocolea monostachya F.Muell

Georgeantha hexandra BG.Briggs \& L.A.S.Johnson

DQ307442

DQ257531

AF148773

DQ307440

DQ307441

DQ307443

DQ257532

Briggs 9342 Oldfield River, W.A.

DQ257519 Meney 920,

Arrowsmith R., W.A.

DQ257523 Briggs 9321, N of Cataby, W.A.

NSW391339

Briggs 9514 Lake Dobson, Tas.

Voucher

NSW415191

NSW391372*

NSW364831*

NSW494429

DQ257528 Meney T20, S

NSW364828*

of Eneabba, W.A.

Briggs 9638, S

NSW716273

of Cunderdin, W.A.

DQ257530 Perkins,

Watheroo National Park., W.A.

Briggs 9480,

NSW 437363

Skipper Road, S of Arrowsmith R., W.A.

Briggs 9653, NE of Arrowsmith R., W.A.

DQ307444 DQ257533 Perkins, Correy Road, NSW709054 $\mathrm{N}$ of Eneabba, W.A.

\section{Flagellariaceae}

Flagellaria indica L.

DQ307445

DQ257515

Marchant, cult. Royal Botanic Gardens Sydney

NSW615132*

\section{Joinvilleaceae}

Joinvillea ascendens

DQ307446

DQ257534

Briggs 9672, cult. ex New Caledonia

NSW612727 Brongn. \& Gris. subsp. glabra Newell

J. plicata

DQ307447

(Hook.f.) T.K.Newell 


\begin{tabular}{|c|c|c|c|c|}
\hline Taxon & $r b c \mathrm{~L}$ & matK & Source & Voucher \\
\hline \multicolumn{5}{|l|}{ Poaceae } \\
\hline $\begin{array}{l}\text { Anomochloa marantoidea } \\
\text { Brongn. }\end{array}$ & AF021875 & AF164381 & & \\
\hline Aristida latifolia Domin & - & AF164413 & & \\
\hline $\begin{array}{l}\text { Aristida congesta } \\
\text { Roem. \& Schult. } \\
\text { subsp. barbicollis } \\
\text { (Trin. \& Rupr.) } \\
\text { de Winter }\end{array}$ & AJ746283 & - & & \\
\hline Arundo donax $\mathrm{L}$. & AJ746284 & AF164408 & & \\
\hline $\begin{array}{l}\text { Danthonia spicata } \\
\text { Roem. \& Schult. }\end{array}$ & U31102 & AF164409 & & \\
\hline Eragrostis capensis Trin. & U31104 & - & & \\
\hline E. grandis Hillebr. & - & AF 312342 & & \\
\hline Melica altissima L. & - & AF164399 & & \\
\hline M. uniflora Retz. & AJ746294 & & & \\
\hline Oryza sativa L. & X15901 & X15901 & & \\
\hline Pharus latifolius L. & AY357724 & AF164388 & & \\
\hline $\begin{array}{l}\text { Streptochaeta spicata } \\
\text { Schrad. ex Nees }\end{array}$ & AJ419949 & AF164383 & & \\
\hline Triticum aestivum $\mathrm{L}$. & NC002762 & NC002762 & & \\
\hline Zea mays L. & X86563 & X86563 & & \\
\hline Zeugites pittieri Hack. & AY632374 & AF144576 & & \\
\hline \multicolumn{5}{|l|}{ Restionaceae } \\
\hline $\begin{array}{l}\text { Anthochortus graminifolius } \\
\text { (Kunth) H.P.Linder }\end{array}$ & $\begin{array}{l}\text { Hardy } \\
\text { pers. comm. }\end{array}$ & $\begin{array}{l}\text { Hardy } \\
\text { pers. comm. }\end{array}$ & Linder et al. 7552 & \\
\hline $\begin{array}{l}\text { Baloskion tetraphyllum } \\
\text { (Labill.) B.G.Briggs } \\
\text { \& L.A.S.Johnson } \\
\text { subsp. tetraphyllum }\end{array}$ & AF148761 & DQ257501 & $\begin{array}{l}\text { Briggs } 9120 \text {, Bicheno, } \\
\text { Tas. }\end{array}$ & NSW365050 \\
\hline Calopsis fruticosa (Mast.) & $\begin{array}{l}\text { Hardy } \\
\text { pers. comm. }\end{array}$ & $\begin{array}{l}\text { Hardy. } \\
\text { pers. comm. }\end{array}$ & Linder et al. 7309 & \\
\hline $\begin{array}{l}\text { Chordifex crispatus (R.Br) } \\
\text { B.G.Briggs \& L.A.S.Johnson }\end{array}$ & DQ307448 & DQ257510 & $\begin{array}{l}\text { Briggs 9446, E of } \\
\text { Wellstead, W.A. }\end{array}$ & NSW422605 \\
\hline Elegia cuspidata Mast. & AF148774 & DQ257512 & $\begin{array}{l}\text { Romanowski s.n., } \\
\text { cultivated }\end{array}$ & NSW255150 \\
\hline \multirow[t]{2}{*}{$\begin{array}{l}\text { Empodisma minus (Hook.f.) } \\
\text { L.A.S.Johnson \& D.F.Cutler }\end{array}$} & DQ307449 & - & $\begin{array}{l}\text { Briggs 9508, } \\
\text { Mt Wellington, Tas. }\end{array}$ & NSW494674 \\
\hline & - & DQ257513 & $\begin{array}{l}\text { Briggs 9135, Mt Tim } \\
\text { Shea, Tas. }\end{array}$ & NSW264841 \\
\hline $\begin{array}{l}\text { Eurychorda complanata } \\
\text { (R.Br.) B.G.Briggs \& } \\
\text { L.A.S.Johnson }\end{array}$ & AF148790 & DQ257514 & $\begin{array}{l}\text { Briggs 9136, Mt Tim } \\
\text { Shea, Tas. }\end{array}$ & NSW264949 \\
\hline $\begin{array}{l}\text { Lepyrodia glauca (Nees) } \\
\text { F.Muell. }\end{array}$ & AF148785 & DQ257521 & $\begin{array}{l}\text { Pate s.n., Brunswick } \\
\text { Junction, W.A. }\end{array}$ & NSW423726 \\
\hline $\begin{array}{l}\text { Platycaulos compressus } \\
\text { (Rottb.) H.P.Linder }\end{array}$ & AY881464 & AY881537 & & \\
\hline $\begin{array}{l}\text { Sporadanthus gracilis (R.Br.) } \\
\text { B.G.Briggs \& L.A.S.Johnson }\end{array}$ & DQ307450 & DQ257525 & $\begin{array}{l}\text { Briggs 9263, W of } \\
\text { Engadine, N.S.W. }\end{array}$ & NSW270154 \\
\hline
\end{tabular}

\section{Typhaceae}


Table 2. Sequencing Primers for amplication of trnK.

\begin{tabular}{|c|c|c|}
\hline Name & Note & Sequence $\left(5^{\prime}-3^{\prime}\right)$ \\
\hline trnK-3914F (monocot) & a & TGGGTTGCTAACTCAATGG \\
\hline MBK-F2 & & TATGAATGGAAAAAACAGCATGTCG \\
\hline $\operatorname{trnK}-710 \mathrm{~F}$ & b & GTATCGCACTATGTATCATTTGA \\
\hline MBK-F3 & & GTATGGGGGCACCCTATTAGTAAACC \\
\hline MBK-R2 & & TCGGCCCAGGTTGGTTTACTAATAGG \\
\hline MBK-R3 & & GAAGTTAATCGTAAACAAGAAGATTG \\
\hline MBKgeoR & c & TCACATTCCGACACATAGGAATTATATAGG \\
\hline $\operatorname{trn} \mathrm{K}-2 \mathrm{R}$ & $\mathrm{b}$ & AACTAGTCGGATGGAGTAG \\
\hline
\end{tabular}

(a) from Johnson and Soltis (1995), shortened at 5 ' end.

(b) from Johnson and Soltis (1995).

(c) designed particularly for Georgeantha.

When Ecdeiocoleaceae is represented by only Georgeantha, the (J,Ge) clade receives $74 \%$ or $79 \%$ from $r b c \mathrm{~L}+$ mat K data. Using $r b c \mathrm{~L}$ alone, the JEP clade is not resolved or resolves to discordant topologies with very low support.

(4) Flagellaria grouped with the JEP families, in a graminid clade that is sister to the restiid clade (Anarthriaceae, Restionaceae, Centrolepidaceae), in analyses of matK or $m a t \mathrm{~K}+r b c \mathrm{~L}$ data. The clade (Flagellaria (JEP)) was found in ML analyses and received $87 \%$ or more support in parsimony analyses. Data from $r b c \mathrm{~L}$ alone was insufficient to resolve the position of Flagellariaceae, which formed a trichotomy with the JEP and restiid clades in such analyses.

(5) When the results of parsimony and ML analyses were compared (Table 3), the interrelationships of the JEP families and of Flagellariaceae were identical under each analysis method, and did not depend on whether ML analyses used the default PAUP* settings (HKY) or the preferred model (TVM+I+G) found by MODELTEST. Including taxa from a range of outgroup families of Poales (Restionaceae, Centrolepidaceae, Anarthriaceae), rather than Flagellaria alone, increased support levels but varying the outgroups did not alter the resultant topologies for the critical nodes. Adding further outgroups from Cyperaceae and Typhaceae seemed to introduce more 'noise' as this reduced the support levels but did not alter the resultant topologies.

(6) We found no indels in mat $\mathrm{K}$ that assisted in resolving the JEP clade. There was a onecodon insertion shared by all members of that clade but absent in the other families. Our data (Table 4) conformed to the findings of Hilu and Alice (1999) who drew attention to variation in the $3^{\prime}$ end of mat $\mathrm{K}$ in Poaceae. There is a single base deletion in the majority of Poaceae, but Anomochloa retains a plesiomorphic condition, as do Joinvilleaceae and Restionaceae. Such a frame-shift indel is also absent from the other families studied, including Ecdeiocoleaceae. A nearby two-codon insertion occurring in the PACC grasses was absent in the other families. Restionaceae, Centrolepidaceae and part of Anarthriaceae (Anarthria but not Hopkinsia and Lyginia) show a onecodon deletion in this area. The codon (CAA) present at this position in Hopkinsia and Lyginia is not matched in other sequences and, in those two genera, a one-codon insertion may have followed a deletion that was shared by the three families. 


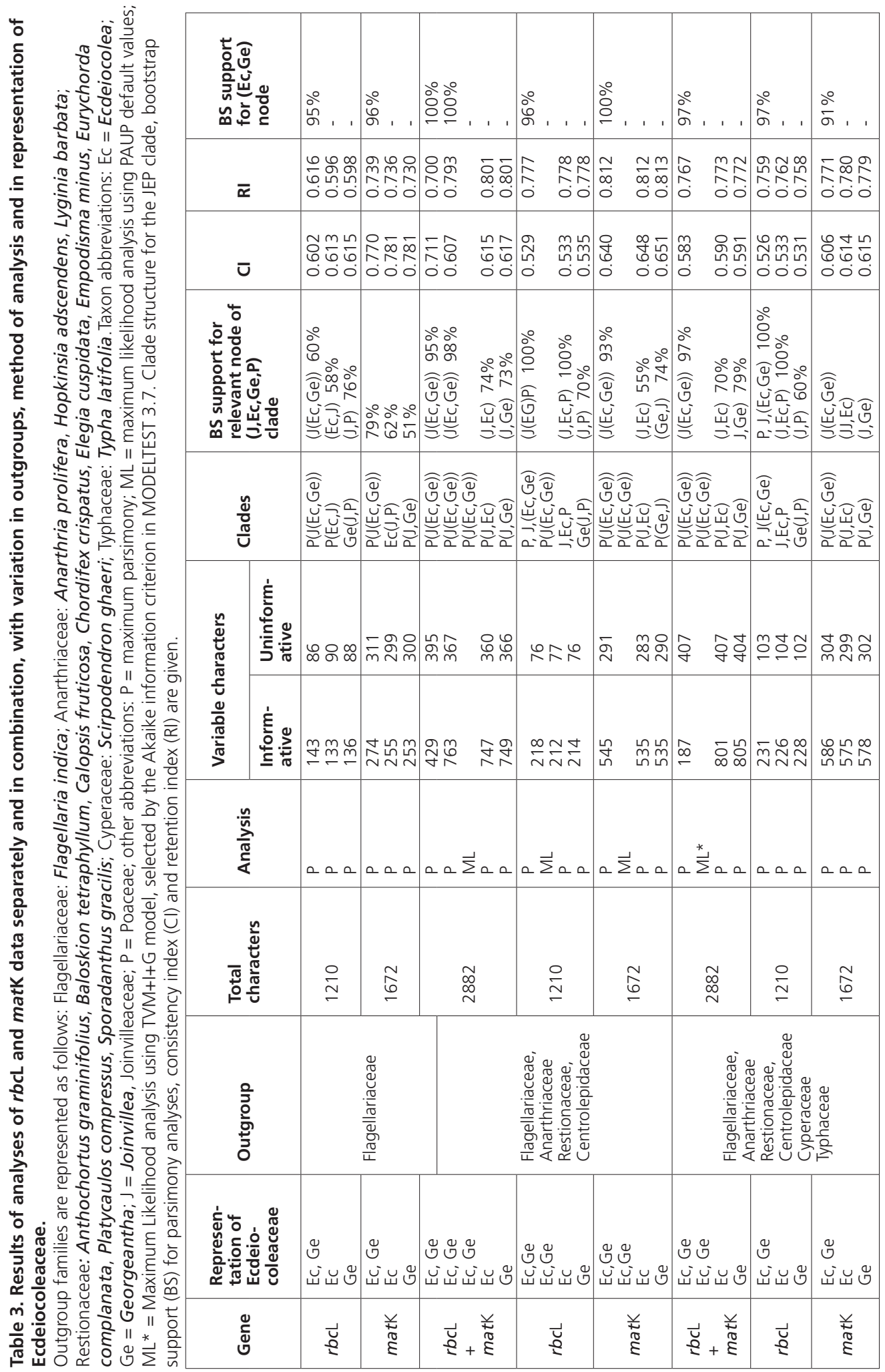


Table 4. Sequence for the $3^{\prime}$ end of matK.

The stop codon is underlined (alignment largely following Hilu and Alice 1999).

Anarthriaceae

Hopkinsia adscendens

Lyginia barbata

Anarthria prolifera

Centrolepidaceae

Centrolepis monogyna

Cyperaceae

Scirpodendron ghaeri

Ecdeiocoleaceae

Ecdeiocolea monostachya

Georgeantha hexandra

Flagellariaceae

Flagellaria indica

Joinvilleaceae

Joinvillea ascendens

Joinvillea plicata

Poaceae

Anomochloa marantoidea

Aristida latifolia

Arundo donax

Danthonia spicata

Eragrostis grandis

Melica altissima

Oryza sativa

Pharus latifolius

Streptochaeta spicata

Triticum aestivum

Zea mays

Zeugites pittieri

Restionaceae (African)

Anthochortus graminifolius

Calopsis fruticosa

Elegia cuspidata

Platycaulos compressus

Restionaceae (Australian)

Chordifex crispatus

Baloskion tetraphyllum

Empodisma minus

Eurychorda complanata

Typhaceae

Sporadanthus gracilis

Typha latifolia

$\begin{array}{lr}\text { CTGGTGAATCGTCAA } & \text { TAA } \\ \text { CTGGTGAATCCTCAA } & \text { TAA } \\ \text { CTGGTGAATCAT-TAA } & \text { TAA } \\ \text { CTAGCAAATCTG } & \text { TAA }\end{array}$

CTGGTGAATTATTCT_ - TAA

CTGGTGAATCATTCT—

CTGGTGAATCATTGG_ — IAA

CTGGTGAATCATTCT - TAA

CTGGTGAATCATTCT—

CTGGTGAATTACTCT_ TAA

CTGGTGAATC-CTCTTACTCTTAATTAA

CTGGTGAATC-CTCTTATTCTTAATTAA

CTGGTGAATC-CTCTTACTCTTAATIAA

CTGGTGAATC-CCCTTACTCTTAATTAA

CTGGTGAACC-CTCT_ TAATTAA

CTGGTGAATC-CTCT—TAATTAA

CTGGTGAATC-CTGA—TAATTAA

CTGGTGAATCATTCT—TAATIAA

CTGGTGAATC-CTCT_ TAATTAA

CTGGTGAATC-CTCTTACTCTTAATTAA

CTGGTAAATC-CTC TTACTTATAATIAA

CTGGCGAATCTT- $\frac{\text { TAA }}{\text { CTGGCGAACCTTTCATTT_ TAA }}$
CTGGCGATCCT- TAA
CTGGCGAATCTTTCATTATGGATCATGA*

CTGGCAAATCCG— TAA

CTAGCAAATCTG—TAA

CTGGCAAATCTC

CTGGCAAATCCG

CTGGCAAATCTT—

TTAGTGAACCATTGA —

*there are 29 additional nucleotides in this sequence (not shown); terminating with a TGA stop codon.

Table 5. Presence of $\mathbf{2 8} \mathbf{~ k b}$ inversion in the chloroplast genome: results from this study and previous reports on the same genera.

\begin{tabular}{|c|c|}
\hline Family & Taxon \\
\hline \multirow[t]{2}{*}{ Anarthriaceae } & Anarthria prolifera \\
\hline & $\begin{array}{l}\text { Hopkinsia adscendens } \\
\text { Hopkinsia anoectocolea }\end{array}$ \\
\hline Ecdeiocoleaceae & $\begin{array}{l}\text { Ecdeiocolea monostachya } \\
\text { Georgeantha hexandra }\end{array}$ \\
\hline Flagellariaceae & Flagellaria indica \\
\hline Restionaceae & Lepyrodia glauca \\
\hline
\end{tabular}

\section{$28 \mathrm{~kb}$ inversion Previous reports}

absent

absent in $A$. scabra

absent

present

present

present

absent

absent
(Michelangeli et al. 2003)

present (Michelangeli et al. 2003)

absent (Doyle et al. 1992) 
(7) The 28-kb inversion in the chloroplast genome was found to be present in three taxa (Table 5), while its absence in three other taxa was confirmed.

\section{Discussion}

Rate of nucleotide substitution: previous studies have drawn attention to the unusually high rate of nucleotide substitution, compared with other angiosperms, in the DNA of $r b c \mathrm{~L}$ in Poaceae. Such long branch lengths in other Poales were noted by Bremer (2000) and are evident in the multi-gene analyses of Graham et al. (2006), Chase et al. (2006) and Givnish et al. (2006). Branch lengths in Ecdeiocoleaceae are similarly long, unlike those of Joinvilleaceae (Fig. 1).

Phylogenetic results: there is robust support in all trees for the major clades and relationships previously identified in Poales sens. strict. by Briggs et al. (2000), Bremer (2002), Michelangeli et al. (2003), Chase et al. (2006) and Graham et al. (2006). In particular, strongly supported clades here are (Poaceae, Ecdeiocoleaceae, Joinvilleaceae) and (Restionaceae, Centrolepidaceae). We also find robust support for the monophyly of Ecdeiocoleaceae. The two genera of Ecdeiocoleaceae, each regarded as monotypic until the very recent discovery of a second species of Ecdeiocolea (not yet named), show great similarity in vegetative and reproductive structures, including highly distinctive culm anatomy, shapes and textures of floral parts, seed ornamentation and an unusual reproductive biology (i.e. a form of monoecy with multiple switching between the production of female and male flowers along the length of the spike). Differences between Georgeantha and Ecdeiocolea include the former's trimerous flowers and dehiscent fruits. Michaelangeli et al. (2003) suggested that, if the indehiscent fruit type is homologous in Ecdeiocolea and Poaceae, these may be more closely allied than either of them is to Georgeantha, whereas Rudall et al. (2005) interpreted the dehiscence of Georgeantha fruits as the result of a character reversal. In view of the overall morphological similarity between Ecdeiocolea and Georgeantha, it is surprising that both $r b c \mathrm{~L}$ and matK show considerable divergence between them. Indeed, from $r b c \mathrm{~L}$ data, an age estimate of more than 55 my BP for their divergence is given by Bremer (2002), and 73 my BP by Janssen and Bremer (2004), comparable to the age of crown Poaceae.

The trees from our mat $\mathrm{K}$ and our combined data agree with Bremer (2002), Chase (2004) and Chase et al. (2006) in finding Poales sens. strict. to divide into a graminid and a restiid clade, with Flagellaria associating with the JEP families to form the graminid clade, while (Anarthriaceae (Restionaceae, Centrolepidaceae)) form the restiid clade. By contrast, the insufficiently resolved $r b c \mathrm{~L}$ tree placed Flagellaria, Anarthriaceae and (JEP families + Restionaceae including Centrolepidaceae) at a trichotomy, a position for Flagellaria more in agreement with the results from combined data of morphology, atpA and rbcL (Michelangeli et al. 2003). Graham et al. (2006) and Givnish (2006) found Flagellaria to be sister to a clade including both Poaceae and Restionaceae. Data from $r b c \mathrm{~L}, m a t \mathrm{~K}$ and $t r n \mathrm{~L}-\mathrm{F}$ relevant to relationships within the restiid clade will be presented elsewhere.

Presence of 28-kb inversion in chloroplast genome: this inversion has previously been reported (Doyle et al. 1992, Michelangeli et al. 2003) as present in Ecdeiocolea, Joinvillea and all Poaceae sampled, but as absent in Flagellaria and Anarthria. Our findings are in agreement with these earlier reports for Ecdeiocoleaceae and Flagellariaceae. 
There have been discordant findings in Restionaceae since these authors reported the inversion as present but Katayama and Ogihara (1996) reported it as absent in the restionaceous genera they studied; our evidence also indicated its absence in Lepyrodia. The results for the two species of Hopkinsia are discordant and this genus should be investigated further. The strong amplification in $H$. anoectocolea, indicating presence of the inversion, was unexpected since results for $H$. adscendens and Anarthria indicated that the inversion was not present.

\section{Conclusion}

Determining whether Ecdeiocoleaceae alone or (Ecdeiocoleaceae, Joinvilleaceae) is sister to Poaceae has a parallel in endeavours to determine whether the basal branch of the angiosperms is Amborella or (Amborella, Nymphaeales). Studies by Zanis et al. (2002) and Leebens-Mack et al. (2005) give a salutary warning against accepting as conclusive a topology with high bootstrap support but limited taxon sampling.

Our study supports the clade (Ecdeiocoleaceae, Joinvilleaceae) as sister to Poaceae. However, others (Chase 2004, Chase et al. 2006, Graham pers. com.) have investigated a wider range of genes in the Poales and found support for Ecdeiocoleaceae alone as the sister group. Adding Georgeantha to the sampling of Ecdeiocoleaceae, as in our study, greatly increases support for the ((Joinvilleaceae, Ecdeiocoleaceae) Poaceae) topology.

\section{Acknowledgments}

We thank Darren Crayn, Margaret Heslewood, Andrew Perkins, Chris Quinn, Helen Stevenson, John Thomson, and Peter Weston for assistance, helpful discussions or comment on the manuscript. Carolyn Porter and Simon Gilmore contributed to the sequencing studies. Jerrold Davis, Kathy Meney, John Pate, Andrew Perkins, Carolyn Porter and Patricia Meagher assisted with fieldwork or provided plant materials or DNA samples. We thank Mark Chase, Jerrold Davis, Sean Graham, Chris Hardy and Peter Linder for making findings and manuscripts available to us in advance of publication. The helpful comments of a reviewer are also acknowledged.

\section{References}

APG (2003) An update of the Angiosperm Phylogeny Group classification for the orders and families of flowering plants: APG II. Botanical Journal of the Linnean Society 141: 399-436.

Barker NP, Clark LG, Davis JI, Duvall MR, Guala GF, Hsiao C, Kellogg EA, Linder HP, MasonGamer R, Mathews S \& Spangler R (2000) A phylogeny of the grass family (Poaceae), as inferred from eight character sets. Pp. 3-7 in Jacobs SWL \& Everett J (eds) Grasses: systematics and evolution. (CSIRO: Melbourne)

Bremer K (2000) Early Cretaceous lineages of monocot flowering plants. Proceedings of the National Academy of Sciences of the USA 97: 4707-4711.

Bremer K (2002) Gondwanan evolution of the grass alliance of families (Poales). Evolution 56: 1374-1387.

Briggs BG, Marchant AD, Gilmore S, \& Porter CL (2000) A molecular phylogeny of Restionaceae and allies. Pp. 661-671 in Wilson KL \& Morrison D (eds) Monocots: systematics and evolution. (CSIRO: Melbourne) 
Campbell CS \& Kellogg EA (1987) Sister group relationships of the Poaceae. Pp. 217-224 in Soderstrom TR, Hilu KW, Campbell CS \& Barkworth ME (eds) Grass systematics and evolution. (Smithsonian Institution Press: Washington)

Chase MW (2004) Monocot relationships: an overview. American Journal of Botany 91: 16451655.

Chase MW, Fay MF, Devey DS, Maurin O, Rønsted N, Davies TJ, Pillon Y, Petersen G, Seberg O, Tamura MN, Asmussen CB, Hilu K, Borsch T, Davis JI, Stevenson DW, Pires JC, Givnish TJ, Sytsma KJ, McPherson MA, Graham SW \& Rai HS (2006) Multi-gene analyses of monocot relationships: a summary. Monocots: Comparative Biology and Evolution. Proceedings of 3rd International Conference on Monocotyledons. Aliso 22: 63-75.

Chase MW, Stevenson DW, Wilkin P \& Rudall PJ (1995) Monocot systematics: a combined analysis. Pp. 685-730 in Rudall PJ, Cribb PJ, Cutler DF \& Humphries CJ (eds) Monocotyledons: systematics and evolution. (Royal Botanic Gardens: Kew)

Cutler DF (1969) Anatomy of the Monocotyledons IV. Juncales. (Oxford University Press: Oxford)

Cutler DF \& Shaw HKA (1965) Anarthriaceae and Ecdeiocoleaceae: two new monocotyledonous families, separated from the Restionaceae. Kew Bulletin 19: 489-499.

Doyle JJ, Davis JI, Soreng RJ, Garvin D \& Anderson MJ (1992) Chloroplast DNA inversions and the origin of the grass family (Poaceae). Proceedings of the National Academy of Sciences of the USA 89: 7722-7726.

Duvall MR (2003) Phylogeny of the grasses (Poaceae) revisited. P.23 in Monocots III Abstracts.(Rancho Santa Ana Botanic Garden: California)

Felsenstein J (2004) PHYLIP (Phylogeny Inference Package) version 3.6. Distributed by the author. (Department of Genome Sciences, University of Washington, Seattle: Washington)

GPWG (2001) Phylogeny and subfamilial classification of the grasses (Poaceae). Annals of the Missouri Botanical Garden 88: 373-457.

Givnish TJ, Pires JC, Graham SW, McPherson MA, Prince LM, Patterson TB, Rai HS, Roalson EH, Evans TM, Hahn WJ, Millam KC, Meerow AW, Molvray M, Kores PJ, O’Brien HE, Hall JC, Kress WJ \& Sytsma KJ (2006) Phylogenetic relationships of monocots based on the highly informative plastid gene $n d h \mathrm{~F}$ : evidence for widespread concerted convergence. Monocots: Comparative Biology and Evolution. Proceedings of 3rd International Conference on Monocotyledons. Aliso 22: 28-51.

Graham SW, Zgurski JM, McPherson MA, Cherniawsky DM, Saarela JM, Horne EFC, Smith SY, Wong WA, O’Brien HE, Biron VL, Pires JC, Olmstead RG, Chase MW \& Rai HS (2006) Robust inference of monocot deep phylogeny using an expanded multigene plastid data set. Monocots: Comparative Biology and Evolution. Proceedings of 3rd International Conference on Monocotyledons. Aliso 22: 3-21.

Hall TA (1999) BioEdit: a user-friendly biological sequence alignment editor and analysis program for Windows 95/98/NT. Nucleic Acids Symposium Series 41: 95-98.

Hilu KW (2004) Phylogenetics and chromosomal evolution in the Poaceae (grasses). Australian Journal of Botany 52: 13-22.

Hilu KW \& Alice LA (1999) Evolutionary implications of matK indels in Poaceae. American Journal of Botany 86: 1735-1741.

Janssen T \& Bremer K (2004) The age of major monocot groups inferred from $800+r b c \mathrm{~L}$ sequences. Botanical Journal of the Linnean Society 146: 385-398.

Johnson LA \& Soltis DE (1995) Phylogenetic inference in Saxifragaceae sensu stricto and Gilia (Polemoniaceae) using matK sequences. Annals of the Missouri Botanical Garden 82: 149-175.

Katayama H \& Ogihara Y (1996) Phylogenetic affinities of the grasses to other monocots as revealed by molecular analysis of chloroplast DNA. Current Genetics 29: 572-581.

Kellogg EA (2000) The grasses: a case study in macroevolution. Annual Review of Ecology and Systematics 31: 217-238. 
Leebens-Mack J, Raubeson LA, Cui L, Kuehl JV, Fourcade MH, Chumley TW, Boore JL, Jansen RK \& dePamphilis CW (2005) Identifying the basal angiosperm node in chloroplast genome phylogenies: sampling one's way out of the Felsenstein zone. Molecular Biology and Evolution 22: 1948-1957.

Linder HP \& Rudall PJ (2005) Evolutionary history of Poales. Annual Review of Ecology, Evolution, and Systematics 36: 107-124.

Michelangeli FA, Davis JI \& Stevenson DW (2003) Phylogenetic relationships among Poaceae and related families as inferred from morphology, inversions in the plastid genome, and sequence data from the mitochondrial and plastid genomes. American Journal of Botany 90: 93-106.

Posada D \& Crandall KA (1998) MODELTEST: testing the model of DNA substitution. Bioinformatics 14: 817-818.

Rudall PJ, Stuppy W, Cunniff J, Kellogg EA \& Briggs BG (2005) Evolution of reproductive structures in grasses (Poaceae) inferred by sister-group comparison with their putative closest living relatives, Ecdeiocoleaceae. American Journal of Botany 92: 1432-1443.

Stevenson DW \& Loconte H (1995) Cladistic analysis of monocot families. Pp. 543-578 in Rudall PJ, Cribb PJ, Cutler DF \& Humphries CJ (eds) Monocotyledons: systematics and evolution. (Royal Botanic Gardens: Kew)

Swofford DL (2001) PAUP*: phylogenetic analysis using parsimony (and other methods). Version 4.0b10. (Sinauer, Sunderland: Massachusetts)

Zanis MJ, Soltis DE, Soltis PS, Mathews S \& Donoghue M (2002) The root of the angiosperms revisited. Proceedings of the National Academy of Sciences of the USA 99: 6848-6853.

Manuscript received 19 July 2006, accepted 20 March 2007 